Dickinson sorving as sole or joint honorary secretary for the whole period except for the two years of his presidency 1932-34, when A. Stowers took office. The growth of the Society can be traced in successive annual reports published in the Transactions. The first volume of Transactions - that published in 1922occupied 83 pages, and contained six papers and a list of 120 members ; volume 20, 1939-40 (the last before the War), exceeded 180 pages and contained twenty papers, while the annual report gave the membership as 1,512. Since then the membership has risen to more than 5,000, principally due to the activities of the American members. Besides the papers, the Transactions have contained a valuable analytical bibliography of the history of engineering and applied science. The Newcomen Society owes much to Dr. Dickinson for his long service as secretary, and also for his editorship of nearly every volume of the Transactions. It has, therefore, been decided to invite subscriptions to a Dr. Dickinson Presentation Fund, the proceeds from which will be given to Dr. Dickinson in the form of a cheque or be expended on objects chosen by him. The upper limit for subscriptions is fixed at $£ 22 s$. Members wishing to subseribe are asked to send their sub. seriptions, not later than October 10, to the assistant secretary, Miss G. Bingham, O.B.E., 43 King's Road, Chelsea, S.W.3, made payable to the "Dr. Dickinson Presentation Fund". Dr. Dickinson will be entertained to dinner after the annual general meeting on November 14, when the presentation will be made.

\section{University and Research Libraries}

THE University and Research Section of the Library Association held its first week-end conference since 1938 on September 21-24 at Wadham College, Oxford. The Conference was well attended, and visits were paid to many of the Oxford college and other libraries. The general meeting of the Section held on September 22 and 23 was concerned chiefly with the discussion, amendment and final approval of the Committee's proposals for the postwar development of university and research libraries. As soon as they are approved by the Library Association Council, they will be issued to the general public. Reference has already been made in Nature (Dec. 11, 1943 , p. 687 ; February 19, 1944, p. 203) to these proposals which are intended to ensure an adequate supply of books and other materials for the prosecution of research in Britain. They deal with the place of university and research libraries in a national system, the national and local organization for research, administration and staffing, and plead for the fullest co-ordination of all library facilities. But this cannot be achieved until the national library resources have been comprehensively and qualitatively surveyed, a long overdue piece of bibliographical research. The programme of such a survey has been prepared by a committee of the Section's and it is hoped that funds will eventually be forthcoming for the project.

M. Henri Lemaître, a vice-president of the Library Association and formerly librarian of the Bibliothèque Nationale, was unable to attend through illness to deliver his promised address. Fortunately, a copy had arrived, and was translated and read to the session. M. Lemaitre outlined the story of French libraries and librarians during the Gorman occupation, a record of destruction and racial discrimination. During 1940-45, more than two million books were lost through the ravages of war, many of them forming the irreplaceable local collections in which France abounded. Many thousands of books, including complete libraries, were seized by the Germans. Yet French librarians stood firm against all threats, and continued to serve their readers to the best of their ability. In their private lives and in their professional occupation they were in the van of the struggle against the Nazis, and many suffered imprisonment and death for their devotion. Despite Nazi opposition they maintained a supply of books to French prisoners of war. They continued to supply books on the various proscribed lists to trustworthy readers; and when liberation came, they were ready with their plans for rehabilitation with the creation of new book centres for the French people on the lines of the English county library system.

\section{Grants for Dental Teaching and Research}

THE Nuffield Foundation has agreed to make grants for the promotion of dental teaching and research in Great Britain. The assistance provided by the Foundation is to be in three parts. First, grants totalling $£ 9,000$ a year for ten years are to be made to the Sutherland Dental School, University of Durham; University of Leeds Dental School; the Turner Dental School, University of Manchester; and Guy's Hospital Dental School, for the development of research work on preventive dentistry. Secondly, Nuffield dental fellowships will be established to improve the supply of dental research workers and teachers. Lastly, a few scholarships to enable dental students of outstanding ability to receive a more thorough scientific training will be awarded. Fellowships will be open to three groups of candidates: those with dental qualifications, university graduates in medicine, and thirdly those holding a university science degree; the annual value will be between $£ 400$ and $£ 800$. Scholarships, providing tuition fees and a subsistence allowance not exceeding $£ 200$ a year, are intended for candidates who, in the opinion of their dental school, would profit by receiving, during their course of training, additional instruction in anatomy and physiology. Forms of application for fellowships and studentships may be obtained from the Secretary of the Nuffield Foundation, 12-13 Mecklenburgh Square, London, W.C.1.

\section{Announcements}

Mr. Arohibald N. Black has been appointed Donald Pollock reader in engineering science in the University of Oxford.

Dr. J. E. HuRst, technical director of Bradley and Foster, Ltd., Bradleys Concrete, Ltd., of Darlaston, and director of research of the Staveley-Bradley, Foster Research Laboratory Institute at Sheepbridge, is to be Sheriff of the City and County of Lichfield. Dr. Hurst is president of the Staffordshire Iron and Steel Institute, and is known for his work on the heat treatment of cast-iron and the development of cast-iron suitable for nitrogen hardening.

The Stephen Paget Memorial Lecture of the Research Defence Society is being resumed this year and will be given by Sir William Savage on the occasion of the annual general meeting of the Society, the title being "Public Health and its Debt to Experimental Medical Research". The meeting will be held at Manson House, Royal Society of Tropical Medicine and Hygiene, London, on October 12. 